\title{
Systemic Study of Aerosol Loading and Retention over Praia-Cape Verde: Satellite and Ground Observation Analysis
}

\author{
Moses Eterigho Emetere ${ }^{1 *}$, Marvel L. Akinyemi ${ }^{1}$, Modupe Ojewumi² \\ ${ }^{1}$ Department of Physics, Covenant University Canaan land, P.M.B 1023, Ota, Nigeria \\ ${ }^{2}$ Department of Chemical Engineering, Covenant University Canaan land, Ota, Nigeria
}

Received: 3 March 2017

Accepted: 3 April 2017

\begin{abstract}
The situation in Praia may be critical at the moment because of its current aerosol loading and retention. In this study we obtained 14-year (2000-13) data set from satellite and ground observation from a multi-angle imaging spectro-radiometer (MISR) and an aerosol robotic network (AERONET). The analytic and statistical techniques were used to investigate the aerosol loading and retention over Praia-Cape Verde. The average annual aerosol retention over the study area increased by $18 \%$. The highest aerosol retention rate of $39 \%$ was recorded in 2010. The aerosol loading was found to be higher between December to February. Since the ventilation over Praia is low, aerosol loading impact on the health and welfare of life forms may be threatened. The study also suggested other sectors of the economy that can be affected by the increased aerosol loading over Praia.
\end{abstract}

Keywords: aerosol retention, aerosol loading, satellite observation, ground observation, analytical technique, statistical technique, Praia

\section{Introduction}

The challenge of aerosol-loading to human health and infrastructure is enormous. Liu et al. [1] affirmed that atmospheric aerosols can increase the heat flux over the earth. Verheggen and Weijers [2] clarified that aerosols cause cooling while black carbon aerosol causes warming. Emetere et al. [3-4] worked on the cooling/warming effect of aerosol loading over some locations in West Africa. It was proposed that atmospheric aerosols coagulate in form of heterogeneous and homogeneous layers that

*e-mail: emetere@yahoo.com have lifetimes which depend on how much aerosols are retained.

Atmospheric aerosol consist of a mixture of inorganic salts, organic carbon, black carbon, trace metals, and water [5]. The moving aerosol layers in the atmosphere may be detrimental to signal budgeting. It has been confirmed that aerosols are harmful to telecommunication infrastructures. At the moment, the technique for estimating atmospheric aerosol retention is still unknown. The proportion of the aerosol constituents varies with time and location. The volume of pollution could aid scattering and absorbing of solar radiation [6]. This idea is complex and still remains a scientific gap.

General aerosol characteristics can be investigated through the examination of aerosols retained in the 
atmosphere. This process is called aerosol retention, which is quite interesting and cannot be generalized because of its dynamic properties. These properties depend mainly on geographical location. Aerosol retention in the atmosphere modifies indirectly the properties of clouds. Verheggen and Weijers [2] proposed that aerosol retention has the potential to reduce global warming "to a certain extent." Hence the need to be certain about the permissive level of aerosols in the atmosphere is novel at this point.

Aerosol loading over West Africa is already at its alarming state and new facts have shown that aerosol retention is very high in the region [3]. Hence, our main objective in this paper is to investigate the permissive level of aerosols over Praia's atmosphere.

The main focus of this research is to avert the danger aerosol loading portends for the more than 200,000 inhabitants of Praia. For example, there has been an annual temperature increase to about $1^{\circ} \mathrm{C}$ in the last 15 years. Lopes et al. [7] confirmed that the level of air pollution in Praia and its environs calls for urgent examination. This has greatly affected the rainfall pattern in Praia. For example, Varela and Molion [8] had argued that rain-producing events in Praia are due to winds coming from the southwestern quadrant over the warm Atlantic Ocean, that is, associated with frontal systems traveling eastward and not the inter-tropical continental zone (ITCZ ) or African squall. In the case of Praia, the rain-producing events, when traced from 1981 to 2009 by Varela and Molion [8], show that more scientific facts can be infered. A recent study [7] has shown that thermal stress had increased in Praia in recent years. In August and October, the thermal stress is above $29^{\circ} \mathrm{C}$ and can be as high as $40^{\circ} \mathrm{C}$ in poorly ventilated streets. Thermal stress is associsted with diseases [9]. We therefore propose that these events are inter-related and are currently triggerred by atmospheric aerosol loading/retention.

This paper uses analytical and statistical techniques to investigate the state of aerosol loading and retention over Praia. We used the standard error (SE) of mean (in this research) to estimate the population mean for each month of the year. SE technique defines the standard deviation of the mean for each month. The standard error of the mean is expressed mathematically as:

$$
S E=\frac{\sigma}{\sqrt{n}}
$$

... where ' $\sigma$ ' is the population standard deviation and ' $n$ ' is population size. Standard error measures the uncertainty in aerosol optical depth parameter and the deviations of the monthly mean from the 13-year mean. Standard deviation $(\sigma)$ measures the amount of visible dispersion from the monthly mean [10].

The coefficient of variation is the measure of a normalized dispersion. In statistics, coefficient of variation is referred to as relative standard deviation and expressed as a percentage. Coefficient of variation is not used for few meteorological parameters because of the inconsistency of its interval scale. For example, coefficient of variation is appropriate for the Kelvin scale and inappropriate for the Celsius scale because its data has an interval scale.

Therefore, we adopted the coefficient of variation because it gives an appropriate comparison between yearly and monthly AOD means. Coefficient of variation can be represented mathematically as:

$$
C V=\frac{\sigma}{\mu}
$$

...where $\sigma$ is the standard deviation and $\mu$ is the monthly mean.

Praia is the second most populous city in Cape-Verde and it is located on longitude $23.51^{\circ} \mathrm{W}$ and latitude $14.92^{\circ} \mathrm{N}$ in the Sahelian geographic region, i.e., south of the Sahara (Fig. 1). Due to its proximity to the Sahara desert (about $1,749 \mathrm{~km}$ ), the northeast winds as well Sahara dust play a significant role in its aerosol loading and retention. Also, Praia is under the influence of the local steppe climate. Its metropolitan area is about $699 \mathrm{~km}^{2}$. Praia has an average temperature and precipitation of $27^{\circ} \mathrm{C}$ and $268 \mathrm{~mm}$.

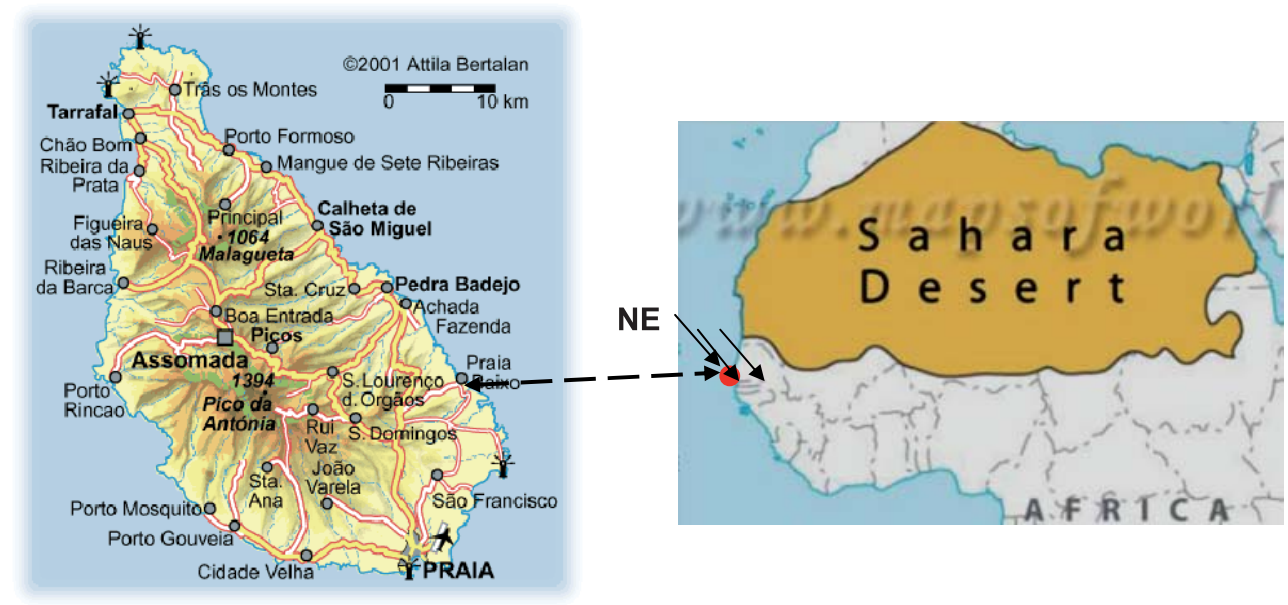

Fig. 1. Map of Praia and the Sahara influence 
Fourteen years satellite and ground observations were obtained from the multi-angle imaging spectroradiometer (MISR) and aerosol robotic network (AERONET), respectively. The MISR operates at various directions, i.e., nine different angles $\left(70.5^{\circ}, 60^{\circ}, 45.6^{\circ}, 26.1^{\circ}, 0^{\circ}\right.$, $\left.26.1^{\circ}, 45.6^{\circ}, 60^{\circ}, 20.5^{\circ}\right)$ and gathers data in four different spectral bands (blue, green, red, and near-infrared) of the solar spectrum. The blue band is at wavelength $443 \mathrm{~nm}$, the green band is at $555 \mathrm{~nm}$, the red band 670 $\mathrm{nm}$, and the infrared band is $865 \mathrm{~nm}$. MISR acquires images at two different levels of spatial resolution, i.e., local and global modes. It gathers data at the local mode of $275 \mathrm{~m}$ pixel size and $1.1 \mathrm{~km}$ in the global mode. Typically, the blue band is to analyze coastal and aerosol studies. The green band is to analyze Bathymetric mapping and estimating peak vegetation. The red band analyzes the variable vegetation slopes and the infrared band analyzes biomass content and shorelines.

\section{Material and Methods}

Analytical and statistical techniques were used to investigate aerosol loading and retention, respectively. The aerosol dispersion model that was propounded by Emetere et al. [3] was used to test the validity of the satellite and ground observations. The raw MISR and AERONET dataset was processed using the Excel package. The means for each month were calculated for each year. The assimilated data was inserted into the Matlab curve-fitting tool based on equation (3):

$$
\begin{gathered}
\psi(\lambda)=a_{1}{ }^{2} \cos \left(\frac{\mathrm{n}_{1} \pi \tau(\lambda)}{\mathrm{k}_{\mathrm{y}}}+\alpha\right) \cos \left(\frac{\mathrm{n}_{1} \pi \tau(\lambda)}{\mathrm{k}_{\mathrm{z}}}+\alpha\right) \\
+a_{2}{ }^{2} \cos \left(\frac{\mathrm{n}_{2} \pi \tau(\lambda)}{\mathrm{k}_{\mathrm{y}}}+\beta\right) \cos \left(\frac{\mathrm{n}_{2} \pi \tau(\lambda)}{\mathrm{k}_{\mathrm{z}}}+\beta\right)
\end{gathered}
$$

...where $\alpha$ and $\beta$ are the phase differences, $\mathrm{k}$ is diffusivity, $\tau$ is $\mathrm{AOD}, \psi$ is the concentration of contaminant, $\lambda$ is the wavelength, and $a$ and $n$ are atmospheric and tuning constants, respectively. The atmospheric constants can be used to measure the optical state of Praia.

The percentage of aerosol retention can be determined from the coefficient of variance for each year. This was done by considering the previous and current years that were denoted as $G_{P}$ and $G_{r}$, respectively. The ground observations from the AERONET were adopted in the statistical technique. Hence we propound that aerosol retention between two years can be calculated using equation (4):

$$
A=\left|\frac{G_{P}-G_{r}}{G_{P}}\right|^{2} \times 100 \%
$$

\section{Results and Discussion}

The AOD pattern in Praia-Cape Verde is normally distributed, that is, it has a Bell curve (Fig. 2). The

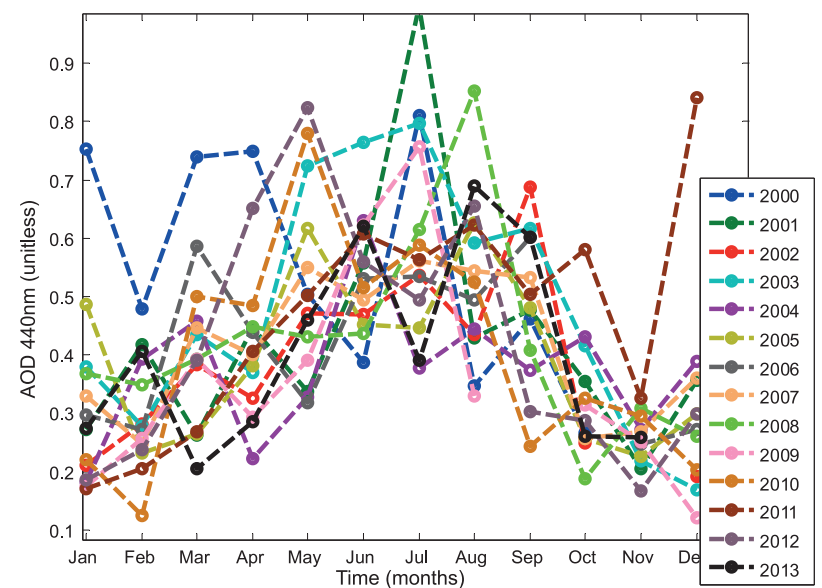

Fig. 2. AOD pattern for Praia (2000-13).

maximum AOD value was found in June and July, which is very different from other locations in West Africa [3-4]. Also, the minimum AOD was found in January and December. From literature, Praia has a unique climate [11]. For example, its rainy season can be found in May and September, and the dry season in January, February, March, and August. The results shown in Fig. 2 denote that the self-cleansing atmospheric mechanism, e.g., "rain wash" do not have much influence on reducing aerosol loading over Praia.

The aerosols loading over Praia was tested using equation (3). Equation (3) from the previous application [3] was built specifically for West African aerosol loading. The year 2001 was selected based on the general aerosol optical depth shown in Fig. 2 to prove that the analytical model is accurate and can be used to determine aerosol loading over Praia (Fig. 3). It was discovered that only December was slightly out of the analytical model. It was observed (Figs 2-3) that the aerosol loading over Praia is high during December. Since the major occupation of the area is farming, it is expected that anthropogenic emissions (via bush burning) and the natural aerosol loadings from the northeast dusty winds would be high. Aside from the

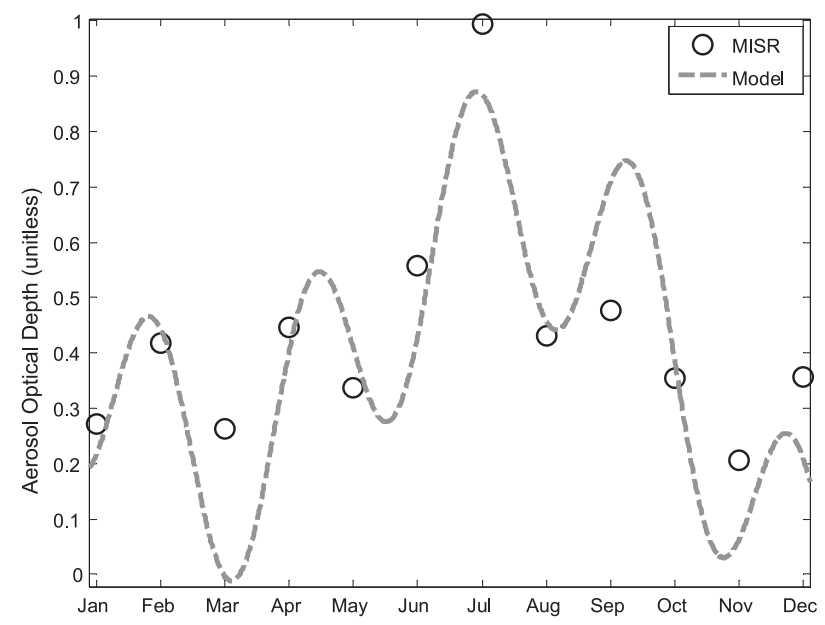

Fig. 3. AOD for new model and MISR for 2001. 
Emetere M.E., et al.

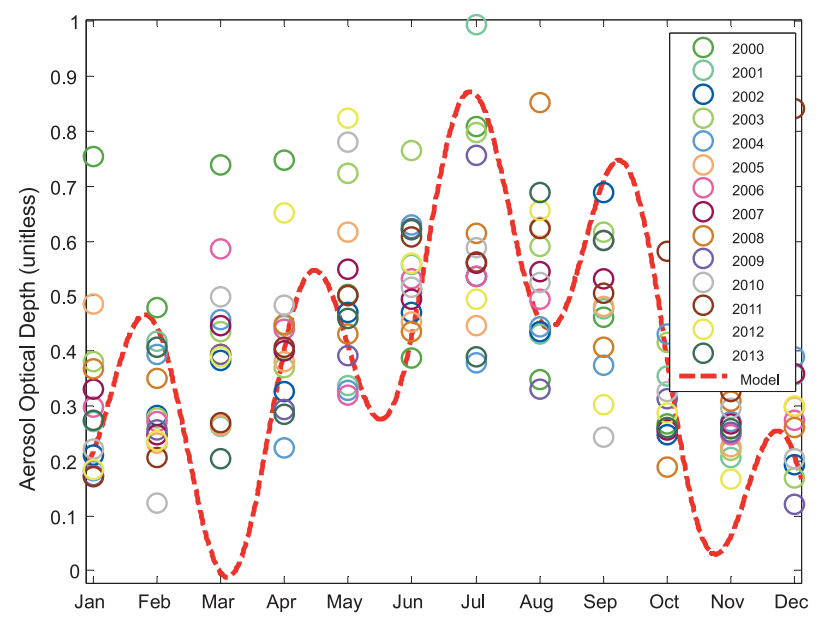

Fig. 4. AOD for new model and MISR for the year 2000-2013

earlier explanation, it could be infered that ventilation is lowest in December, i.e., by observation. This assertion is still subject to future investigation. In other words, it could be deduced from the general aerosol loading from 2000 to 2013 that there had been constant complications in December (Fig. 4).

In addition to the general features that can be obtained from Figs 2-4, the optical state could be obtained from Equation (3). The optical state in the context of this paper refers to the cumulative effect of all kind of atmospheric layers that are made-up largely of gas and aerosols. Three major parameters was used to explain the optical state over an area, i.e., atmospheric constants, phase differences, and tuning constants. Hence, the optical state can be inferred from the Matlab curve fit tool and Equation (3) as shown in Table 1.

The effect of the optical state on satellite and ground observations over Praia will be investigated in the later part of this section. The optical state has several important elements, including the enhancement of measuring devices and signal budgeting. The use of the optical state to determine the constants inserted into the compact flash of measuring devices is important. The anomalies of large data loss both in ground and satellite observations in West Africa are largely dependent on the wrong atmospheric constants for the measuring instruments. It is important to note that this paper has significant interest in the ITU model because it suggests an alteration to its model (i.e., see Equation (5)):

$$
\begin{gathered}
N=\frac{77.6 P}{T}+3.73 \times 10^{5} \frac{e}{T^{2}}= \\
N_{d r y}+N_{\text {wet }}(N-\text { units })
\end{gathered}
$$

Table 2. Statistical analysis of ground and satellite data set.

\begin{tabular}{|c|c|c|c|c|}
\hline \multirow{2}{*}{$\begin{array}{c}\text { Statistical } \\
\text { Parameters }\end{array}$} & \multicolumn{2}{|c|}{2000} & \multicolumn{2}{c|}{2001} \\
\cline { 2 - 5 } & Ground & Satellite & Ground & Satellite \\
\hline Standard error & 0.017 & 0.054 & 0.072 & 0.054 \\
\hline $\begin{array}{c}\text { 95\% confidence } \\
\text { interval }\end{array}$ & 0.042 & 0.123 & 0.159 & 0.118 \\
\hline Variance & 0.002 & 0.030 & 0.062 & 0.035 \\
\hline $\begin{array}{c}\text { Standard } \\
\text { deviation }\end{array}$ & 0.045 & 0.172 & 0.250 & 0.186 \\
\hline $\begin{array}{c}\text { Coefficient of } \\
\text { variation }\end{array}$ & 0.164 & 0.412 & 0.677 & 0.606 \\
\hline Skew & 0.775 & 0.216 & 1.825 & 2.065 \\
\hline Kurtosis & -0.384 & -1.759 & 2.219 & 5.243 \\
\hline $\begin{array}{c}\text { Kolmogorov- } \\
\text { Smirnov stat }\end{array}$ & 0.194 & 0.169 & 0.390 & 0.226 \\
\hline
\end{tabular}

...where e is water vapour pressure, $\mathrm{P}$ is atmospheric pressure (hpa), and $\mathrm{T}$ is absolute temperature $(\mathrm{K})$. The mathematical relationship between relative humidity and water vapor pressure is expressed in the following equation:

$$
e=\frac{R H}{100} a \exp \left[\frac{b T}{T+c}\right]
$$

...where $\mathrm{T}$ is the temperature in the above equation given in ${ }^{\circ} \mathrm{C}$, and the coefficients $\mathrm{a}, \mathrm{b}$, and $\mathrm{c}$ take the following values: $a=6.1121, b=17.502$, and $c=240.97$. The implication of this research is hinged on the results from Leck and Svensson [12], that the determination of coefficients $\mathrm{a}, \mathrm{b}$, and $\mathrm{c}$ are influenced by the optical state over a geographical location. This study proposes an inclusion of a term that considers the attenuation due to the moving aerosols layer and the incorporation of the latter into the ITU model. Upon this concept, we statistically examine the satellite and ground observations over Praia as shown in Tables 2 to 8 .

From Tables 2 to 8 , the shaded box signifies the highest value of the ground observation for Praia between 2001 and 2012. The shaded box signifies the highest value of the satellite observation for Praia between 2001 and 2012. The shaded box signifies the lowest value of the ground observation for Praia between 2001 and 2012. The red box signifies the lowest value of the satellite observation for Praia between 2001 and 2012.

The highest coefficient of variance for the ground data set was observed in 2010 and the lowest in 2000 . The maximum coefficients of variance for the satellite data set were observed in 2009 and the minimum in

Table 1. Atmospheric constants over Praia.

\begin{tabular}{|c|c|c|c|c|c|c|}
\hline Location & $a_{1}$ & $a_{2}$ & $n_{1}$ & $n_{1}$ & $\alpha$ & $\beta$ \\
\hline Praia & 0.6645 & 0.7712 & 0.08138 & 0.3432 & 0 & 0 \\
\hline
\end{tabular}


Table 3. Statistical analysis of ground and satellite data set.

\begin{tabular}{|c|c|c|c|c|}
\hline \multirow{2}{*}{$\begin{array}{c}\text { Statistical } \\
\text { Parameters }\end{array}$} & \multicolumn{2}{|c|}{2002} & \multicolumn{2}{c|}{2003} \\
\cline { 2 - 5 } & Ground & Satellite & Ground & Satellite \\
\hline Standard error & 0.050 & 0.038 & 0.034 & 0.053 \\
\hline $\begin{array}{c}\text { 95\% confidence } \\
\text { interval }\end{array}$ & 0.110 & 0.084 & 0.075 & 0.117 \\
\hline Variance & 0.030 & 0.016 & 0.014 & 0.034 \\
\hline $\begin{array}{c}\text { Standard } \\
\text { deviation }\end{array}$ & 0.173 & 0.126 & 0.118 & 0.185 \\
\hline $\begin{array}{c}\text { Coefficient of } \\
\text { variation }\end{array}$ & 0.577 & 0.433 & 0.396 & 0.497 \\
\hline $\begin{array}{c}\text { Skew } \\
\text { Kurtosis }\end{array}$ & 1.542 & 0.502 & -0.409 & 0.402 \\
\hline $\begin{array}{c}\text { Kolmogorov- } \\
\text { Smirnov stat }\end{array}$ & 0.213 & 0.162 & 0.134 & 0.155 \\
\hline
\end{tabular}

Table 4. Statistical analysis of ground and satellite data set.

\begin{tabular}{|c|c|c|c|c|}
\hline \multirow{2}{*}{$\begin{array}{c}\text { Statistical } \\
\text { Parameters }\end{array}$} & \multicolumn{2}{|c|}{2004} & \multicolumn{2}{c|}{2005} \\
\cline { 2 - 5 } & Ground & Satellite & Ground & Satellite \\
\hline Standard error & 0.108 & 0.031 & 0.047 & 0.034 \\
\hline $\begin{array}{c}\text { 95\% confidence } \\
\text { interval }\end{array}$ & 0.343 & 0.069 & 0.103 & 0.074 \\
\hline Variance & 0.047 & 0.012 & 0.027 & 0.014 \\
\hline $\begin{array}{c}\text { Standard } \\
\text { deviation }\end{array}$ & 0.216 & 0.108 & 0.163 & 0.117 \\
\hline $\begin{array}{c}\text { Coefficient of } \\
\text { variation }\end{array}$ & 0.637 & 0.383 & 0.486 & 0.402 \\
\hline Skew & -0.020 & 0.002 & 1.386 & 0.348 \\
\hline Kurtosis & -0.206 & 0.330 & 1.615 & -0.992 \\
\hline $\begin{array}{c}\text { Kolmogorov- } \\
\text { Smirnov stat }\end{array}$ & 0.133 & 0.160 & 0.215 & 0.190 \\
\hline
\end{tabular}

Table 5. Statistical analysis of ground and satellite data set.

\begin{tabular}{|c|c|c|c|c|}
\hline \multirow{2}{*}{$\begin{array}{c}\text { Statistical } \\
\text { Parameters }\end{array}$} & \multicolumn{2}{|c|}{2006} & \multicolumn{2}{c|}{2007} \\
\cline { 2 - 5 } & Ground & Satellite & Ground & Satellite \\
\hline Standard error & 0.040 & 0.034 & 0.035 & 0.028 \\
\hline $\begin{array}{c}\text { 95\% confidence } \\
\text { interval }\end{array}$ & 0.090 & 0.076 & 0.076 & 0.061 \\
\hline Variance & 0.016 & 0.013 & 0.014 & 0.009 \\
\hline $\begin{array}{c}\text { Standard } \\
\text { deviation }\end{array}$ & 0.125 & 0.113 & 0.120 & 0.095 \\
\hline $\begin{array}{c}\text { Coefficient of } \\
\text { variation }\end{array}$ & 0.404 & 0.359 & 0.415 & 0.304 \\
\hline Skew & 0.490 & 0.021 & 0.295 & -0.043 \\
\hline Kurtosis & -0.243 & -2.057 & -1.173 & -1.453 \\
\hline $\begin{array}{c}\text { Kolmogorov- } \\
\text { Smirnov stat }\end{array}$ & 0.139 & 0.246 & 0.167 & 0.207 \\
\hline \multicolumn{2}{|c|}{} & & \multicolumn{2}{|c|}{} \\
\hline
\end{tabular}

Table 6. Statistical analysis of ground and satellite data set.

\begin{tabular}{|c|c|c|c|c|}
\hline \multirow{2}{*}{$\begin{array}{c}\text { Statistical } \\
\text { Parameters }\end{array}$} & \multicolumn{2}{|c|}{2008} & \multicolumn{2}{c|}{2009} \\
\cline { 2 - 5 } & Ground & Satellite & Ground & Satellite \\
\hline Standard error & 0.023 & 0.045 & 0.032 & 0.055 \\
\hline $\begin{array}{c}\text { 95\% confidence } \\
\text { interval }\end{array}$ & 0.050 & 0.100 & 0.071 & 0.122 \\
\hline Variance & 0.006 & 0.025 & 0.012 & 0.033 \\
\hline $\begin{array}{c}\text { Standard } \\
\text { deviation }\end{array}$ & 0.078 & 0.157 & 0.111 & 0.182 \\
\hline $\begin{array}{c}\text { Coefficient of } \\
\text { variation }\end{array}$ & 0.360 & 0.485 & 0.450 & 0.667 \\
\hline Skew & 0.738 & 1.685 & 1.230 & 1.501 \\
\hline Kurtosis & -0.110 & 3.351 & 1.955 & 1.972 \\
\hline $\begin{array}{c}\text { Kolmogorov- } \\
\text { Smirnov stat }\end{array}$ & 0.175 & 0.274 & 0.159 & 0.256 \\
\hline
\end{tabular}

Table 7. Statistical analysis of ground and satellite data set.

\begin{tabular}{|c|c|c|c|c|}
\hline \multirow{2}{*}{$\begin{array}{c}\text { Statistical } \\
\text { Parameters }\end{array}$} & \multicolumn{2}{|c|}{2010} & \multicolumn{2}{c|}{2011} \\
\cline { 2 - 5 } & Ground & Satellite & Ground & Satellite \\
\hline Standard error & 0.045 & 0.048 & 0.042 & 0.049 \\
\hline $\begin{array}{c}95 \% \text { confidence } \\
\text { interval }\end{array}$ & 0.098 & 0.106 & 0.095 & 0.107 \\
\hline Variance & 0.024 & 0.028 & 0.018 & 0.028 \\
\hline $\begin{array}{c}\text { Standard } \\
\text { deviation }\end{array}$ & 0.155 & 0.167 & 0.133 & 0.168 \\
\hline $\begin{array}{c}\text { Coefficient of } \\
\text { variation }\end{array}$ & 0.732 & 0.552 & 0.375 & 0.468 \\
\hline Skew & 1.999 & 0.537 & 1.116 & 0.061 \\
\hline Kurtosis & 4.462 & -0.210 & 0.868 & -0.683 \\
\hline $\begin{array}{c}\text { Kolmogorov- } \\
\text { Smirnov stat }\end{array}$ & 0.242 & 0.137 & 0.238 & 0.165 \\
\hline
\end{tabular}

Table 8. Statistical analysis of ground and satellite data set.

\begin{tabular}{|c|c|c|c|c|}
\hline \multirow{2}{*}{$\begin{array}{c}\text { Statistical } \\
\text { Parameters }\end{array}$} & \multicolumn{2}{|c|}{2012} & \multicolumn{2}{c|}{2013} \\
\cline { 2 - 5 } & Ground & Satellite & Ground & Satellite \\
\hline Standard error & 0.052 & 0.056 & 0.034 & 0.048 \\
\hline $\begin{array}{c}\text { 95\% confidence } \\
\text { interval }\end{array}$ & 0.123 & 0.124 & 0.075 & 0.108 \\
\hline Variance & 0.022 & 0.038 & 0.014 & 0.026 \\
\hline $\begin{array}{c}\text { Standard } \\
\text { deviation }\end{array}$ & 0.147 & 0.195 & 0.118 & 0.160 \\
\hline $\begin{array}{c}\text { Coefficient of } \\
\text { variation }\end{array}$ & 0.598 & 0.591 & 0.407 & 0.510 \\
\hline Skew & 0.512 & 0.732 & 0.886 & 0.589 \\
\hline Kurtosis & -1.213 & -0.275 & 0.549 & -1.049 \\
\hline $\begin{array}{c}\text { Kolmogorov- } \\
\text { Smirnov stat }\end{array}$ & 0.201 & 0.204 & 0.215 & 0.179 \\
\hline
\end{tabular}


Table 9. Atmospheric aerosol retention over Praia (2001-13).

\begin{tabular}{|c|c|c|c|c|c|c|c|c|c|c|c|c|c|}
\hline Year & 2001 & 2002 & 2003 & 2004 & 2005 & 2006 & 2007 & 2008 & 2009 & 2010 & 2011 & 2012 & 2013 \\
\hline $\begin{array}{c}\text { Aerosol } \\
\text { Retention (\%) }\end{array}$ & 10.2 & 0.25 & 10 & 37.3 & 5.6 & 2.9 & 0.07 & 1.7 & 6.3 & 39.4 & 23.9 & 35.6 & 10.2 \\
\hline
\end{tabular}

2007. It can be inferred from the coefficients of variance for satellite and ground observations that the accuracy of determining aerosol loading is more evident as the years go by. Secondly, the interval between the highest and lowest coefficients of variance for ground observation span a decade and it is higher than satellite observation. This shows that ground observation is more reliable than satellite observation over Praia.

Equation (4) was applied to obtain aerosol retention over Praia as shown in Table 9. The year of highest atmospheric aerosol retention was found between 2009 and 2010 (39.4\%). When aerosol loading and retention is comparatively analyzed, it is observed that the skew and kurtosis are also good indicators for estimating atmospheric aerosol retention. The significance of atmospheric aerosol retention significantly applies to the aviation industry [13], human health [14], measuring instruments, energy budget, and meteorology [15].

By the atmospheric aerosol retention shown in Table 9, the cause of the high thermal stress could be explained. Relatively low aerosol retention was observed in 2003 and 2007, so the thermal stress for the two years should be low. It was observed that in 2009 and beyond, yearly aerosol retention increased. This further confirmed the results of the analytical model that, due to the anomalies observed in the aerosol loading of December, the self-cleansing mechanisms had little influence on aerosol content in Praia and its environs. The predictions of the United Nations Development Programme [16] on the thermal stress in Cape Verde for 50 years could now be explained by the aerosol retention results. Results of yearly precipitation obtained from the Tropical Rainfall Measuring Mission corroborated the role of aerosol retention in determining rain-producing events (Fig. 5) .

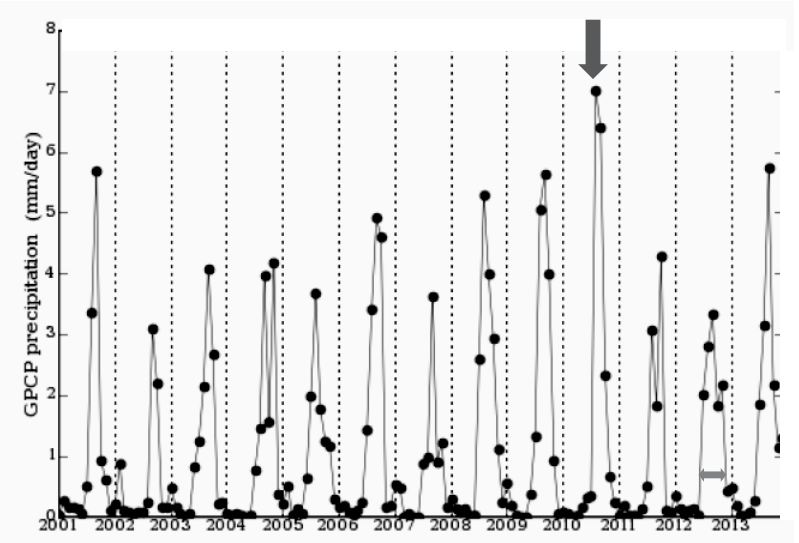

Fig. 5. Precipitation over Praia (2001-13).
The year of highest aerosol retention had the highest precipitation (i.e., see the red arrow in Fig. 5). It was observed that the magnitude of aerosol retention can also reflect an increase in the width of the bell-shaped graph
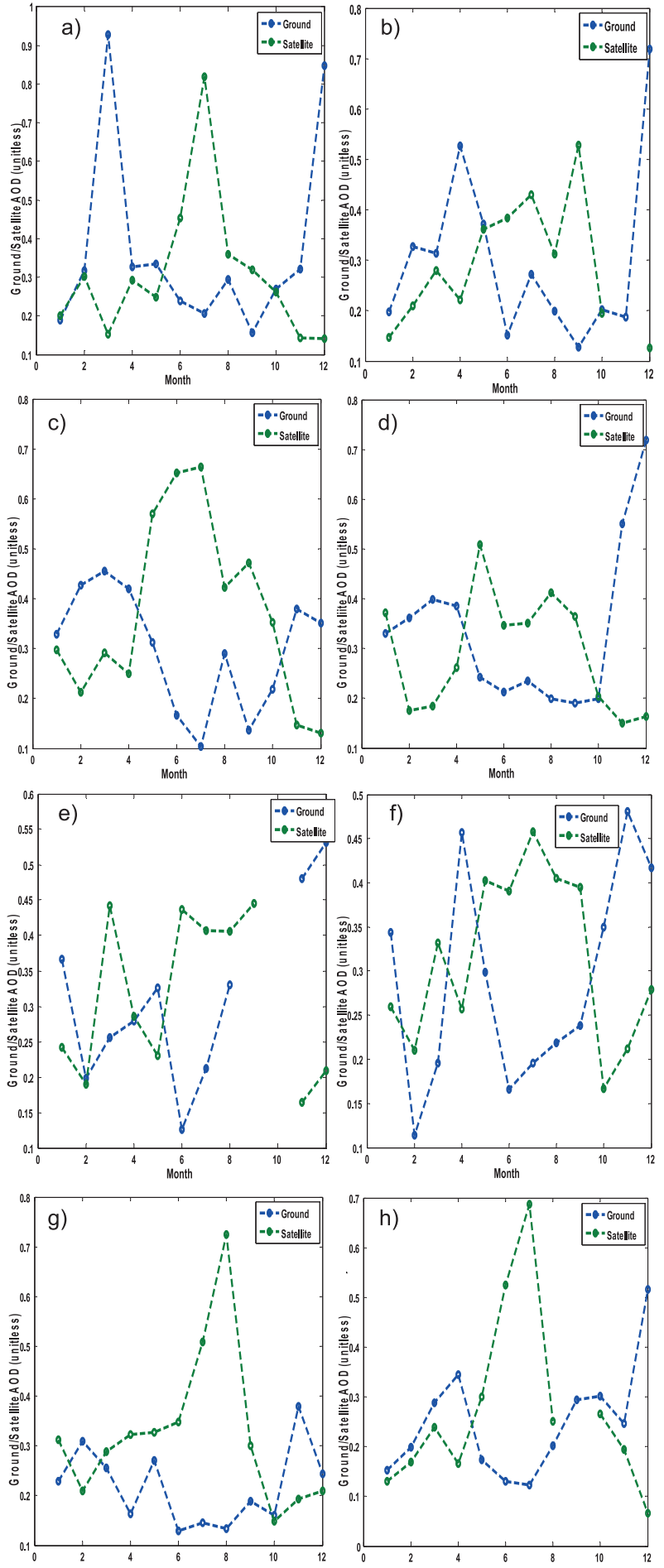

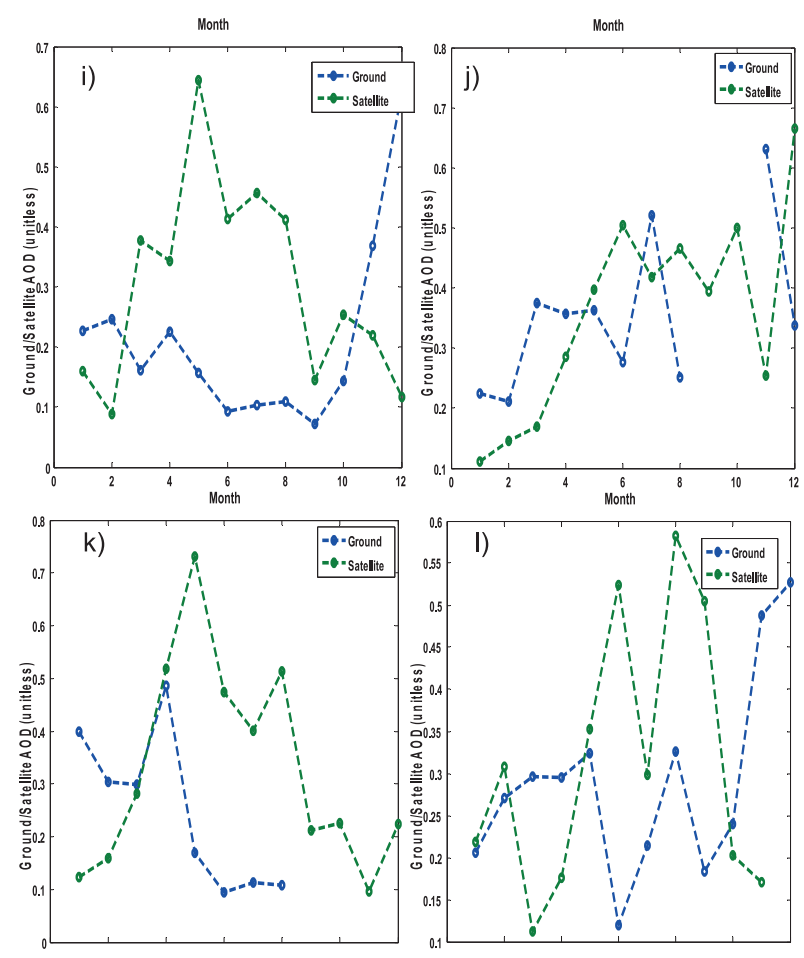

Fig. 6. Ground and satellite observations over Praia for: a) 2001, b) 2002 , c) 2003 , d) 2004 , d) 2005 , e) 2006 , f) 2007 , g) 2008 , h) 2009 , i) 2010 ,j) 2011 , k) 2012, and l) 2013 .

illustrated by the arrow. The increased width of the bell shape denotes that the precipitation naturally extends beyond its usual month (as explained earlier). Hence, this result confirms that aerosol retention plays a vital role in determining rainfall patterns. Therefore, aerosol loading and retention is important to most events already reported on Praia and its environs.

The AOD pattern in Praia is very unique, that is, comparing the satellite and ground observations. This enables unseen events that could be captured by observations per time. It is observed from Fig. 6 that both observations show sharp differences between June and October. While the ground observation follows the usual observation for the tropics, that is, a high AOD during harmattan and low AOD during raining season, the satellite observation was different. In this case, it is suggested that Praia's AOD pattern is dominated by the stratospheric aerosol, which may arise from the influence of oceanic winds to promote the escape of the tropospheric aerosols into the stratosphere [17]. The maximum AOD for ground observation ranges between November and December. This idea is not in agreement with other West African locations. The minimum AOD for the ground observation ranges between February and April.

\section{Conclusions}

It was affirmed that aerosol retention and loading has exceeded normal limits. Hence, the self-cleansing mechanism in the Praia atmosphere could hardly control/ reduce the rate of aerosol loading per year. This idea was confirmed via yearly excessive aerosol loading in December. The average annual aerosol retention over the study area has increased by $18 \%$. The highest aerosol retention was was recorded in 2010 at an all-time highof $39 \%$, which subtly increased the thermal stress over Praia. Also, the results affirmed that aerosol retention plays a vital role in the rain patern of the location. Therefore, aerosol loading and retention is important to understand the events reported on Praia and its environs. The analytical and statistical technique used for this study has shown high accuracy. Therefore, it is recommended that the model can be extended for future study in tropics outside West Africa.

\section{Acknowledgements}

The authors acknowledge NASA for allowing the use their imageries. The authors are thankful to Covenant University for partial sponsorship of the work.

\section{References}

1. LIU J., ZHANQING L. Estimation of cloud condensation nuclei concentration from aerosol optical quantities: influential factors and uncertainties. Atmospheric Chemistry Physics, 14, 471, 2014.

2. VERHEGGEN B., WEIJERS E.P. Climate change and the impact of aerosol: A literature review. Energy Research Center of the Netherlands, 95, 1, 2009.

3. EMETERE M.E., AKINYEMI M.L., AKINOJO O. Parametric retrieval model for estimating aerosol size distribution via the AERONET, LAGOS station. Environmental Pollution, 207 (C), 381, 2015a.

4. EMETERE M.E., AKINYEMI M.L., AKIN-OJO O. Aerosol Optical Depth Trends over Different Regions of Nigeria: Thirteen years Analysis, Modern Applied Science. 9 (9), 267, 2015b

5. PÖSCHL U. Atmospheric Aerosols: Composition, Transformation, Climate and Health Effects. Angewandte Chemie International Edition, 44, 7520, 2005.

6. WANG C., JEONG G.R., MAHOWALD N. Particulate absorption of solar radiation: anthropogenic aerosols vs. dust. Atmospheric Chemistry and Physics Discussions, 9, 3935, 2009.

7. LOPES ANTÓNIO, EZEQUIEL CORREIA, JUDITE M. DONASCIMENTO, PAULO CANÁRIO. Urban bioclimate and comfort assessment in the African city of Praia (Cape Verde). Finisterra, 98, 33, 2014.

8. VARELA-LOPES G.E., MOLION L.C.B. Precipitation Patterns in Cape Verde Islands: Santiago Island Case Study. Atmospheric and Climate Sciences, 4, 854, 2014.

9. AHMED M. ABDEL-GHANY, IBRAHIM M. AL-HELAL, MOHAMED R. SHADY. Evaluation of Human Thermal Comfort And Heat Stress In An Outdoor Urban Setting In Summer Under Arid Climatic Conditions. Environment Protection Engineering, 40 (3), 139, 2014.

10. EMETERE M.E., BOYO A.O., AKINYEMI M.L. Statistical Analysis of the Thermal Comfort in the Urban Climate of Ilorin-Nigeria: A Three Decade Event. Research journal of fisheries and hydrobiology. 10 (11), 178, 2015c. 
11. UNAKA J.N. The Cape Verde Project: Teaching Ecologically Sensitive and Socially Responsive Design, A Ph.D thesis submitted to University of Wisconsin Milwaukee, 1, 2014.

12. LECK C., SVENSSON E. Importance of aerosol composition and mixing state for cloud droplet activation over the Arctic pack ice in summer, Atmospheric Chemistry \& Physics, 15, 2545, 2015.

13. GETTELMAN A., CHEN C. The climate impact of aviation aerosols. Geophysical Research Letters, 40, 1, 2013.

14. WYZGA RONALD E., LAWRENCE J. FOLINSBEE. Health effects of acid aerosols. Water, Air, and Soil Pollution, 85 (1), 177, 1995.
15. EMETERE M.E., AKINYEMI M.L. Modeling Of Generic Air Pollution Dispersion Analysis From Cement Factory. Analele Universitatii din Oradea-Seria Geografie 231123628, 181, 2013.

16. UNITED NATIONS DEVELOPMENT PROGRAMME, http://country-profiles.geog.ox.ac.uk (accessed on 5 July 2015).

17. HOMMEL R., TIMMRECK C., GIORGETTA M.A., GRAF H.F. Quasi-biennial oscillation of the tropical stratospheric aerosol layer. Atmospheric Chemistry Physics, 15, 5557, 2015. 